\title{
Infection of susceptible/tolerant barley genotypes with Barley yellow dwarf virus alters the host plant preference of Rhopalosiphum padi clones depending upon their ability to transmit BYDV
}

\author{
Maria Kern $^{1}$ D $\cdot$ Torsten Meiners $^{2}$ (D) $\cdot$ Edgar Schliephake $^{1} \cdot$ Antje Habekuss $^{1}$ (D) Frank Ordon $^{1}$ (D) $\cdot$ Torsten Will $^{1}$ (D)
}

Received: 12 June 2020 / Revised: 8 March 2021 / Accepted: 23 March 2021 / Published online: 12 April 2021

(c) The Author(s) 2021

\begin{abstract}
Discovering mechanisms of plant-virus-vector interactions is fundamental to understand their ecology and evolution and to apply this knowledge in plant protection. To study the influence of varying Barley yellow dwarf virus (BYDV) transmission efficiencies on host plant preference of Rhopalosiphum padi (L.) clones, we performed host choice experiments with two barley cultivars (BYDV susceptible cv. 'Rubina' and BYDV tolerant cv. 'Vixen') including healthy and virus-infected plants. For the susceptible barley cultivar 'Rubina', aphid clone R07 (high transmission efficiency) preferred BYDV-infected over healthy host plants after $24 \mathrm{~h}$, while clones D10 (medium transmission efficiency) and R09 (low transmission efficiency) preferred neither host. In contrast, BYDV infection of 'Vixen' did not affect the plant's appeal for aphid clone R07. Host plant access, indicated by ingestion and observed by electrical penetration graph technique for a period of $2 \mathrm{~h}$, was facilitated on BYDV-infected cv. 'Rubina' for the clones R07 and D10, whereas an opposite effect was observed for the clone R09. For R07 and R09, the difference was not visible after a period of $5 \mathrm{~h}$. As observed earlier for BYDV-infected wheat, enhanced emission of volatile organic compounds associated with virus-induced attraction was detected for BYDV-infected cv. 'Rubina.' It is concluded that host plant preference is possibly linked with a high BYDV transmission efficiency as observed for the clone R07, leading to a fitness advantage of this clone as indicated by early increased ingestion. This advantage is not present on BYDV-tolerant genotypes most likely due to the absence of infection symptoms.
\end{abstract}

Keywords Rhopalosiphum padi $\cdot$ Barley yellow dwarf virus $\cdot$ Aphid-virus-plant interaction · Induced volatiles · Aphid clone $\cdot$ Host-plant selection

\section{Key message}

Communicated by J. Gross.

Maria Kern and Torsten Meiners shared first author.

Torsten Will

torsten.will@julius-kuehn.de

1 Institute for Resistance Research and Stress Tolerance, Julius Kühn Institute (JKI) - Federal Research Centre for Cultivated Plants, Erwin-Baur-Str. 27, 06484 Quedlinburg, Germany

2 Institute for Ecological Chemistry, Plant Analysis and Stored Product Protection, Julius Kühn Institute (JKI) - Federal

Research Centre for Cultivated Plants, Königin-Luise-Str. 19, 14195 Berlin, Germany
- Aphid populations of a species are composed of different clones that may differ in their skills. Here, it is studied how clone-specific BYDV transmission efficiency may affect host preference of the aphid species Rhopalosiphum padi.

- Changes in volatile emission due to Barley yellow dwarf virus infection in a susceptible cultivar only attract the clonewith a high transmission efficiency for BYDV.

- Our data indicate that this skill may provide ecological benefits for such aphid clones.

- A tolerant BYDV-infected barley variety does not attract these clones. 


\section{Introduction}

The interactions between plants, plant viruses and arthropod virus vectors are multitrophic and complex. Discovering the mechanisms mediating these interactions is fundamental for understanding their ecology and evolution and for the implementation of this knowledge in plant protection, e.g., for the assessment of tolerant/resistant plant varieties. One aspect is that virus infection changes plant physiology which affects the biology of insect vectors. Positive vector responses such as attraction to virusinfected plants may be advantageous for the virus by promoting its spread as has been shown for the interaction of different aphid species with plants infected by persistently transmitted and phloem-located viruses (summarized in Dáder et al. 2017). Another aspect is that the efficiency of virus transmission can differ significantly between clones within a species, as has been shown for Rhopalosiphum padi and Sitobion avenae and the Barley yellow dwarf virus (BYDV) (Habekuss et al. 1999; Bencharki et al. 2000).

Aphids find their host plants by using plant volatile organic compounds (VOCs) for orientation (Powell et al. 2006). Depending on the host range of the aphid species, it uses specific VOCs as host and non-host cues during host finding. In some cases, aphids respond to increasing concentrations of individual compounds; in other cases, only ratios between different compounds in a mixture seem to be of importance for host identification (Bruce et al. 2005; Döring 2014). Plant-emitted VOCs also depend on the physiological status and may act as an indicator for host suitability. For example, in the bird cherry-oat aphid $R$. padi, susceptible wheat plants infected with BYDV were shown to be more attractive for aphids than non-infected plants (Ingwell et al. 2012), leading to shorter development times of the aphids (Jiménez-Martínez et al. 2004a). Subsequent work of Jiménez-Martínez et al. (2004b) and Medina-Ortega et al. (2009) showed that non-viruliferous $R$. padi preferred the odor of susceptible BYDV-infected wheat cultivars over healthy plants, whereas there was no preference for a transgenically modified tolerant wheat line.

The BYDV strain PAV of the genus Luteovirus is a persistently transmitted and phloem-located virus that is transmitted, e.g., by the aphid species $R$. padi (Slykhuis 1967; Jensen 1969). Transmission takes place when aphids are secreting saliva into sieve elements at the point of initial sieve element penetration (Prado and Tjallingii 1994; Gray and Gildow 2003; Tjallingii 2006). The Barley yellow dwarf disease, caused by BYDV, infects barley as well as a large number of other cereals worldwide (D'Arcy 1995). Symptoms of a BYDV infection in barley are stunting and characteristic leaf discolorations (Rochow 1961), while on the cellular level phloem degeneration is observed for susceptible plants together with a decreased size of sieve elements and xylem vessels (Esau 1957; Paulmann et al. 2018). In order to control the spread of vector transmitted viruses, to reduce plant infection and to prevent BYDV-associated economic losses, tolerant genotypes can be used. BYDV tolerance in cultivated barley is mediated by the genes Ryd2 (Schaller et al. 1964), Ryd3 (Niks et al. 2004) as well as additional quantitative trait loci (QTL; Scheurer et al. 2001). Ryd2 has been integrated into several barley cultivars, e.g., 'Vixen' (Parry and Habgood 1986).

Until now, the influence of genetic variation of aphid clones within an aphid species (Loxdale, 2008) has not been taken into account when observing host choice and a response to virus infection. Aphid clones show variations with regard to different parameters like host range (Ferrari et al. 2006), aphid behavior (Braendle and Weisser 2001) as well as in their efficiency to transmit viruses like BYDV (Habekuss et al. 1999).

In this study, we studied healthy and BYDV-infected susceptible and tolerant barley genotypes with three selected $R$. padi clones, differing in their ability to transmit BYDV, to answer two questions:

(i) Does breeding-based BYDV tolerance of a barley genotype influence the host choice of $R$. padi between healthy and BYDV-infected plants?

(ii) Is R. padi preference for a BYDV-infected susceptible barley genotype affected by the ability of that aphid clone to transmit BYDV?

\section{Materials and methods}

\section{Aphid rearing}

Rhopalosiphum padi clones R07 and R09 were collected in 2001 in Russia near St. Petersburg, and D10 was collected in 2000 near Flensburg in Germany. After they were collected, all clones were separately reared in a parthenogenetic state in perspex cages with large gauze-covered windows on 14-28-day-old plants of Hordeum vulgare cv. 'Rubina' in a greenhouse. Environmental conditions were set to $20^{\circ} \mathrm{C}$ with a 16-h:8-h light/dark regime. BYDV-PAV-infected aphids were reared in a growth chamber under comparable environmental conditions as described above.

\section{Plant materials}

Hordeum vulgare cv. 'Rubina' (BYDV-susceptible) and $H$. vulgare cv. 'Vixen' (Ryd2-tolerant) plants were grown in 
a greenhouse at $20^{\circ} \mathrm{C}$ under artificial lightning to maintain a 14-h:10-h L/D period. At the two-leaf stage (BBCH 12 ), plants of each genotype were infested with virus-free (sham) and viruliferous aphids (carrying BYDV-PAV; Šip et al. 2006) of the $R$. padi clone R07, respectively, using custom-made insect clip-cages with five aphids/plant. To ensure a sufficient virus transmission, an incubation period of $48 \mathrm{~h}$ was used (Gray et al. 1991). Subsequently, aphids were removed mechanically and all plants were sprayed with an insecticide (Confidor ${ }^{\circledR}$; Bayer, Germany, concentration $0.035 \%$ ). Treated plants were cultivated in a growth chamber under environmental conditions as described above.

After an incubation period of 4-5 weeks, experiments were conducted using BYDV-infected 'Rubina' plants that showed infection symptoms (stunted growth and yellow discoloration of leaves). Symptom based selection of BYDVinfected plants was not possible for the tolerant plant genotype 'Vixen' due to the absence of infection symptoms.

\section{DAS-ELISA}

The BYDV infection status of all plants from both genotypes was tested by using a double-antibody sandwich enzymelinked immunosorbent assay (DAS-ELISA) to ensure that BYDV plants were infected and sham plants are free of BYDV infection. For DAS-ELISA, $50 \mathrm{mg}$ leaf material of each plant was collected and tested according to Clark and Adams (1977) using a polyclonal antiserum (against BYDV-PAV) produced at the Julius Kühn Institute (JKI). After $1 \mathrm{~h}$ of incubation with the substrate ( $p$-nitrophenyl phosphate), extinction (EXT) was measured at $405 \mathrm{~nm}$ with a microtiter plate absorbance reader model Sunrise (Tecan $\mathrm{GmbH}$, Grödig/Salzburg, Austria). The extinction intensity is a measure of the relative virus content/titer. Lyophilized leaf samples of healthy barley plants were included as 'negative controls' in the test. The threshold for a positive BYDV-PAV infection was calculated at EXT of $>0.06$ ( $x$ (mean negative control) $+3 * S T D$ ). In the different choice experiments, plants with an EXT value below the threshold were excluded from further analysis.

\section{BYDV transmission test}

Randomly selected adult apterous aphids of the $R$. padi clones R07, R09 and D10 from the JKI were collected, and BYDV-PAV transmission tests as reported by Habekuss et al. (1999) were conducted on $H$. vulgare cv. 'Rubina'. The infection rate (percent infected plants) as well as the virus titer of the infected plants was determined by using DAS-ELISA (see above). Three independent replications were conducted with approximately 50-60 plants each.

\section{Aphid behavior observed with the electrical penetration graph technique}

Randomly selected adult apterous aphids of the $R$. padi clones were prepared for behavior observation by EPG measurements (Tjallingii 1978) as previously described (Schliephake et al. 2013). EPGs of the R. padi clone R07 were recorded on the $H$. vulgare genotypes 'Rubina' and 'Vixen', while the $R$. padi clones R09 and D10 were only placed on $H$. vulgare cv. 'Rubina'. Aphids were placed on the lower side of the youngest mature leaf, the EPG recording period was set to $5 \mathrm{~h}$, and recording was started directly after all aphids were placed on respective leaves. For the EPGs, the GIGA-8 EPG amplifier and EPG stylet software (EPG Systems, Wageningen, The Netherlands) were used. Data analysis was conducted with the EPG stylet analysis module, and EPG waveform identification was done according to Tjallingii (1978) and Tjallingii and Hogen Esch (1993), using the Excel-based analysis tool (version 10.8, Schliephake et al. 2013). For every test, new plants and aphids were used with $n=16$ for each aphid clone/ plant cultivar/treatment. Only those recordings that showed plant contact by the aphid within the first hour were analyzed. In total, four parameters (s_Np-summed duration of the absence of contact of the aphid's stylet with the plant (termed non-penetration); s_C-summed duration of stylet pathway activities inside the apoplast including short cell penetrations; s_E2 - summed duration of ingestion of sieve element sap from sieve elements; $\mathrm{s} \_\mathrm{F}$ - summed duration of penetration difficulties) were selected for treatment comparison due to their basic relevance for host plant acceptance and accession. The duration of the respective EPG parameters was summed up at hourly intervals over the recording time of 2 and $5 \mathrm{~h}$.

\section{Choice test}

To observe short-term host choice ( 2 h, Jiménez-Martínez et al. 2004b) and long-term host preference (24 h) of the single $R$. padi clones, dual-choice tests were conducted. For this purpose, a choice arena (see Fig. S1 for arena design) was developed out of a plastic food box with side lengths of $5 \mathrm{~cm} \times 9 \mathrm{~cm}$, a height of $6 \mathrm{~cm}$ and an inner volume of 258 $\mathrm{cm}^{3}$. Holes were cut in a height of approximately $3 \mathrm{~cm}$ and a spacing of $3 \mathrm{~cm}$ in the opposite longer sides of the container, and intact mature leafs that were still attached to the plant were pulled through the holes (one from a healthy and one from a virus-infected plant). The holes were subsequently sealed with foamed plastic. To allow aphids to climb toward the leaves, the inner walls of the plastic container between the holes were covered with filter paper. Thirty randomly selected adult apterous aphids were collected from virus free $H$. vulgare cv. 'Rubina' and were placed in the centre of the 
container. $R$. padi clone R07 was tested on the H. vulgare genotypes 'Rubina' and 'Vixen', while the $R$. padi clones R09 and D10 were tested on H. vulgare cv. 'Rubina', only. Aphids on the leaves were counted in intervals of $15 \mathrm{~min}$ during the first $2 \mathrm{~h}$ and again after $24 \mathrm{~h}$. Choice tests were randomized and conducted under greenhouse conditions (cf. aphid rearing). Two independent replications were conducted for each aphid/plant combination with $n=15$ for each replication.

\section{Analysis of volatile organic compounds}

To compare the volatiles of virus-free and infested barley plants, the air of the headspace was collected from the differentially treated BYDV-PAV-infected vs. uninfected 'Rubina' plants. Only one plant was grown in one pot, since an analysis of infected vs. uninfected 'Vixen' and 'Rubina' plants grown with 11 plants per pot, allowed to separate the plant cultivars 'Vixen' and 'Rubina' from each other on the basis of their volatile emissions by PCA, but a discrimination of sham and BYDV-infected plants was not possible. Detailed information about the volatiles analysis of $H$. vulgare $\mathrm{cv}$. 'Vixen' and 'Rubina' (BYDV-infected and sham) is provided in supplementary material.

The abiotic conditions during headspace collections were $20{ }^{\circ} \mathrm{C} \pm 1{ }^{\circ} \mathrm{C}$, about $50 \% \pm 5 \%$ relative humidity (RH) with daylight. Plant volatile collections were started between 9:00 and 12:00 o'clock local time. The entire setup was wrapped in a flexible polyethylene bag (Toppits $\circledR_{\text {, Cof- }}$ resco Frischhalteprodukte GmbH \& Co. KG, Minden, Germany). The bag was closed at the top by a cable tie. Prior to tightly closing the top, two Teflon tubes were inserted into the opening. Through one of these devices, an adsorption tube $(5 \mathrm{mg}$ activated charcoal filters, Gränicher and Quartero, Daumazan, France) was inserted into the bag. Air was pulled through the adsorption tube with the use of an air-sampling pump (SKC 224-PCXR8KV series, SKC Inc., Houston, TX, USA) for $24 \mathrm{~h}$ at $0.5 \mathrm{l} / \mathrm{min}$. The flow was measured by a battery-operating flowmeter (Aalborg® Model GFM17, 0-1000 ml/min He, Aalborg Instruments \& Controls Inc., NY, USA). Through the other tube, charcoal-filtered air could passively enter into the experimental setup. The VOCs were eluted from the filters with 50/50\% methanol/dichloromethane containing an internal standard (1 ng/ $\mu \mathrm{l} 1$-bromooctane, Aldrich, purity 97\%). The samples were stored at $-20^{\circ} \mathrm{C}$. Prior to analysis by gas chromatography (see below), the eluted samples were concentrated under a stream of nitrogen to a volume of approx. $6 \mu$ l.

Extracts sampled from single plants were analyzed by gas chromatography-flame ionization detection (GC-FID) using an Agilent gas chromatograph $6890 \mathrm{~N}$, fitted with a Macherey-Nagel Optima- 5 column $(30 \mathrm{~m} \times 0.25 \mathrm{~mm}$ i.d., film thickness $=0.25 \mu \mathrm{m})$. Detector and injector temperatures were set at $250{ }^{\circ} \mathrm{C}$. The following oven temperature program was used: heating from 45 to $210^{\circ} \mathrm{C}$ at a rate of $3 \mathrm{~K} /$ min. This final temperature was held for $21.5 \mathrm{~min}$. Carrier gas was hydrogen with a constant flow rate of $1.1 \mathrm{~mL} / \mathrm{min}$ (splitless). Mass spectrometry was performed using a Single Quadrupole Agilent MSD 5975B/GC 6890 N using the same column and oven temperature program as above. Helium was used as carrier gas with a flow rate of $1 \mathrm{~mL} / \mathrm{min}$. Mass spectra were recorded in EI+ mode. The ionization energy was set to $70 \mathrm{eV}$.

Identification of the detected compounds was based on their relative retention times and their mass spectra in comparison with those observed for pure standard substances. The other compounds were tentatively identified by comparison of mass spectra and retention indices (calculated according to van den Dool and Kratz (1963)) with those recorded in the Adams and NIST mass spectral databases and the previously published data (Adams 2014; NIST Chemistry WebBook 2002). The retention indices of individual components were calculated using a series of $n$-alkenes (C8-C40). Compounds for which proper identification was not possible were defined as "unknown" and included in the analysis. Relative proportions of volatile organic compounds were calculated by setting the sum of all selected compounds to $100 \%$.

\section{Statistics analysis}

For analyzing extinction values of BYDV-PAV-infected plants (EXT $>0.06)$ infested by different $R$. padi clones, mean values were compared by analysis of variance following the post hoc mean value comparison according to Tukey $\operatorname{HSD}(\alpha=0.05)$. BYDV-PAV infection rates were compared pairwise by using the Chi-square test. For analyzing choice test results, aphid numbers on sham and BYDV-infected plants were grouped for the respective time points with regard to clone and plant genotype and were first checked for normal distribution with the Shapiro-Wilk $W$ test before applying a $t$-test (two-tailed). Due to the absence of normal distribution, a Mann-Whitney $U$ post hoc test was used to compare aphid behavior data from EPG recordings after EPG parameter analysis by an Excel-based analysis tool (version 10.8, Schliephake et al. 2013).

Statistical tests were conducted by using R and R Studio, version 3.6.2 (R Development Core Team, 2008), including the packages 'car' (Fox and Weisberg 2019), 'Ismeans' (Lenth 2016) and 'emmeans' (Lenth et al. 2019).

Differences in quantities of individual compounds among the different treatments were compared by Mann-Whitney U post hoc tests corrected by Benjamini-Hochberg. Additionally, we analyzed the chemical dataset by a principal component analysis (PCA) (Wold et al. 1987) using the software program SIMCA-P 14.1 (Umetrics AB, Umeå, Sweden). 
The results of a PCA are usually discussed in terms of the loading plot, which describes the relationships between the variables with regard to the PCs (Eriksson et al. 2001).

\section{Results}

\section{Differences in BYDV-PAV transmission between aphid clones}

In order to measure aphid clone-specific virus transmission efficiency, plants were infested by BYDV-carrying aphids of different clones. Relative BYDV-PAV virus titer was measured by DAS-ELISA. Replicated infection experiments were combined for further analysis of the infection rate and the relative virus titer because statistical comparison of replications from one aphid clone by $t$-test did not show any significant differences with regard to extinction. The pairwise comparison of infected and uninfected plants by Chi-square test shows that the infection rates differ between plants that were infested by $R$. padi clones D10 $(n=156$, Infection rate $57.7 \%)$ and $\mathrm{R} 07(n=153$, Infection rate $90.2 \%)\left(\chi^{2}(1\right.$, $n=309)=42.19, p<0.001)$ and between the clones R07 and R09 $(n=166$, infection rate 53.6\% $)\left(\chi^{2}(1, n=319)=51.92\right.$, $p<0.001)$ revealing the highest infection rate for R07. No difference with regard to infection rate was detected between the clones D10 and R09 $\left(\chi^{2}(1, n=322)=0.54, p=0.46\right)$. One-way ANOVA was conducted to compare the effects of $R$. padi clones (D10, R07 and R09) on BYDV-PAV virus titer of plants (Fig. 1). Extinction depended significantly on the aphid clone $(\mathrm{df}=2, F$-value $=361.53, p<0.001)$. Post hoc test comparison (Tukey HSD) indicated that the mean

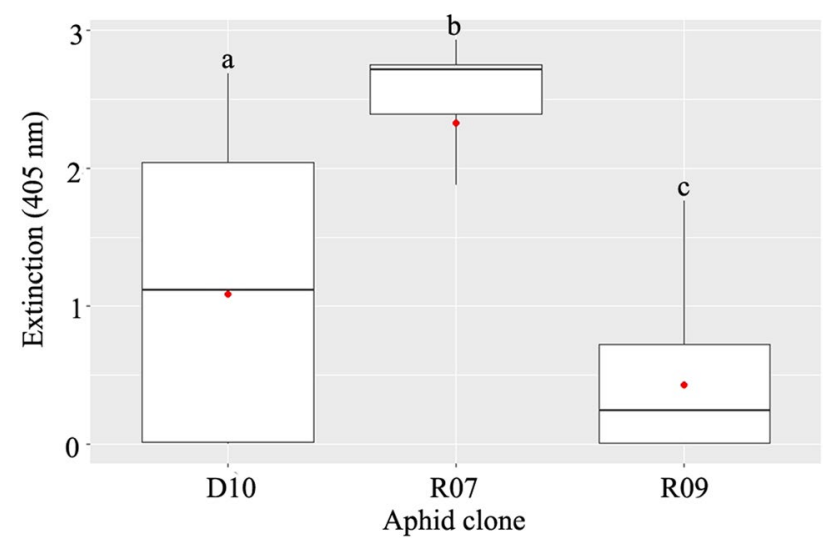

Fig. 1 Relative virus titer of BYDV measured by DAS-ELISA and displayed as extinction in leaf samples of $H$. vulgare cv. 'Rubina' after inoculation with $R$. padi clones D10 $(n=90), \mathrm{R} 07(n=138)$ and R09 $(n=80)$, respectively. The red dot indicates the mean and black lines the median, and whiskers show the upper and lower 1,5xIQR (interquartile range). Statistical test: ANOVA, Tukey HSD post hoc test: $p<0.001$. Different letters indicate significant differences extinction values differ significantly between the three aphid clones tested (Table 1) with the highest extinction for R07 and the lowest for R09. In summary, the R. padi clone R07 showed the highest infection rate and plants infected by BYDV via R07 showed the highest relative virus titer.

\section{Susceptibility of $\boldsymbol{H}$. vulgare genotypes to aphid clones}

EPG recordings were conducted to study potential basic differences in host plant acceptance and accession of different $R$. padi clones within both treatments (sham and BYDV-infected) of the plant cultivars used. While a prolonged period without plant contact (s_NP) indicates a lower acceptance of the host, increased pathway activities of the stylet (s_C) and penetration problems (s_F) indicate difficulties in finding the sieve elements, while decreased ingestion indicates difficulties in establishing a long-term feeding site. An increase of ingestion (s_E2) indicates access to sieve elements.

Significant differences ( $p<0.05$, Mann-Whitney- $U$ test) between treatments (Table 2) were observed after $2 \mathrm{~h}$ of recording for $\mathrm{E} 2$ for all clones and plant genotypes. Ingestion from BYDV-infected plants increased for aphid R07 and R10 on cv. 'Rubina' and decreased for R07 on cv. 'Vixen' and for R09 on cv. 'Rubina'. While the observed difference between the two treatments was detected after a 5-h period for D10 as well, this difference got lost for other clones on the respective $H$. vulgare cultivars. No other significant differences for aphid behavior were observed for the clones D10 and R09. However, R07 showed increased penetration problems after $2 \mathrm{~h}$ on BYDV-infected 'Rubina' and pathway activities of the stylet are decreased after $5 \mathrm{~h}$ on BYDV-infected 'Rubina' and on sham 'Vixen' plants.

Based on the percentages of the respective behavioral parameters (Fig. 2), strong variations can be observed between the clones on sham and BYDV-infected plants. For example, the percentage of s_E2 for R07 and D10 on sham plants cv. Rubina is lower than for clone R09 at both time

Table 1 Influence of $R$. padi clones on relative virus titer (mean extinction values) of infected $H$. vulgare cv. 'Rubina' plants

\begin{tabular}{lcll}
\hline$R$ p padi clone & N infected & $\begin{array}{l}\text { Mean EXT } \\
{[405 \mathrm{~nm}]}\end{array}$ & SD \\
\hline R07 & 138 & $2.58 \mathrm{a}$ & \pm 0.38 \\
D10 & 90 & $1.87 \mathrm{~b}$ & \pm 0.63 \\
R09 & 89 & $0.80 \mathrm{c}$ & \pm 0.47 \\
\hline
\end{tabular}

Relative virus titer was measured in leaf tissue by using DAS-ELISA, and mean values were compared by using post hoc test. Means on the same column followed by different letters are significantly different (Tukey HSD; $p<0.05$ ). N indicates the number of plants successfully infected by respective clones, and SD indicates standard deviation 


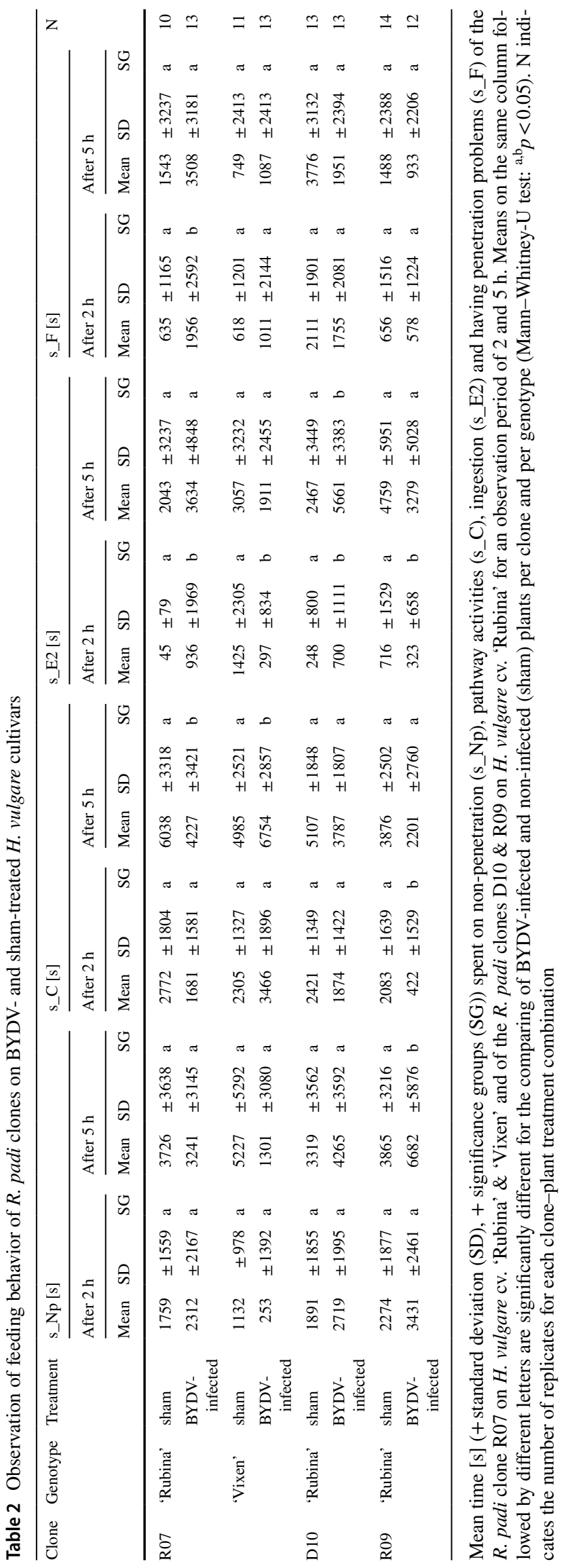


Fig. 2 Percentage of behavioral parameter duration during the recording periods of $2 \mathrm{~h}$ and $5 \mathrm{~h}$ for the $R$. padi clones R07, D10 and R09 on sham-treated and BYDV-infected plants of the $H$. vulgare cv. 'Rubina' and 'Vixen'. The parameters s_Np (non-penetration), s_C (stylet pathway activities), s_E2 (ingestion of sieve element sap) and s_F (penetration difficulties) were selected for treatment comparison

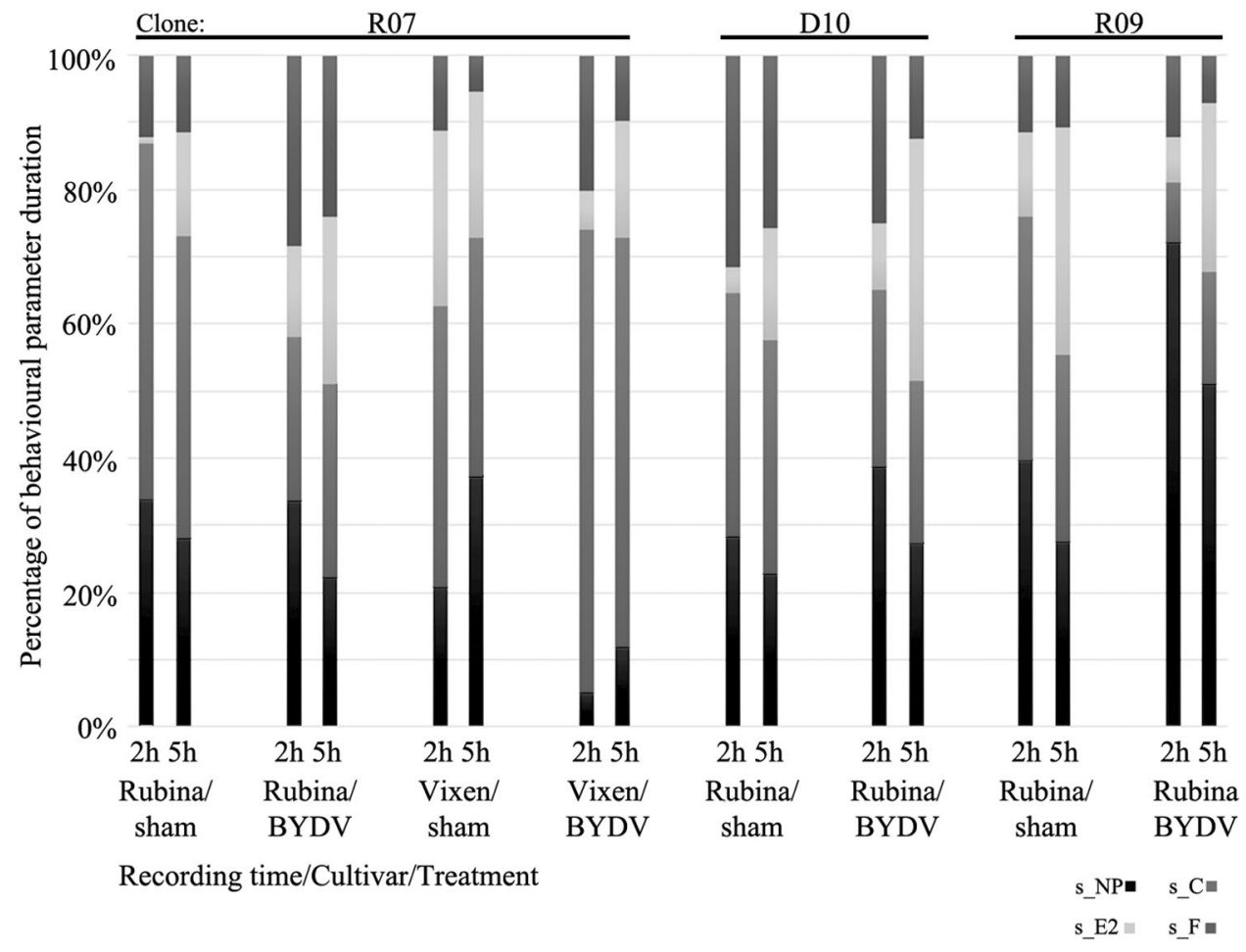

points. While the proportion is higher for both clones on BYDV-infected plants, the proportion of s_E2 decreases for R09. Also striking is the high proportion of s_C for R07 on BYDV-infected plants of cv. 'Vixen' and the high proportion of s_NP for clone R09 on BYDV-infected plants of cv. 'Rubina'.

\section{Short-term and long-term host choice of single $\mathbf{R}$. padi clones}

In order to test the influence of BYDV infection on host choice of aphid clones on the $H$. vulgare cvs. 'Rubina' and 'Vixen, choice tests were conducted for a period of 2 and $24 \mathrm{~h}$. During the observation period of $2 \mathrm{~h}$, aphids on leaves were counted in intervals of $15 \mathrm{~min}$. There was no preference for either plant treatment (BYDV-infected or sham) by any aphid clone during the observation period for the cultivars tested (Fig. 3; ANOVA, Tukey HSD post hoc test: $p>0.05$ ). In contrast to the first $2 \mathrm{~h}$, significant differences were detected regarding plant preference after $24 \mathrm{~h}$ (Fig. 4). In this context, the R. padi clone R07 significantly prefers BYDV-infected cv. 'Rubina' (Fig. 4a, two-tailed $t$-test: $* p<0.01, n=9-15)$. Infected plants of both cultivars showed a high virus titer, but a significantly higher relative titer was detected for the cv. 'Vixen' (Fig. S2). With regard to differences when observing host choice of the clones D10, R07 and R09 on cultivar 'Rubina' (Fig. 4b, two-tailed $t$-test: $* p<0.01, n=8-15)$ only R07 shows a significant preference for the virus-infected plants as described above. However, there appears a slight, but not significant, tendency for the clone D10 to prefer BYDV-infected plants.

\section{Volatiles analysis of $\boldsymbol{H}$. vulgare cv. 'Rubina' (BYDV-infected and sham)}

A principal component analysis (PCA) was used to compare the volatile patterns of plants of the cultivar 'Rubina' not infected and infected with BYDV-PAV with respect to the relative quantities of their volatile compounds (relative to the sum of quantities of all compounds). In this trial with single potted 'Rubina' plants, the PCA (Fig. 5) explained a total of $67.6 \%$ of the variance of the data with $52.7 \%$ by the first and $14.9 \%$ by the second principal component. The score plot (Fig. 5a) of the relative amount of volatile compounds of the two different treatments showed that non-infected 'Rubina' plants $(\mathrm{R}-)$ cluster together and infested 'Rubina' plants $(\mathrm{R}+)$ cluster together based on their chemical profiles. In the loading plot, variables not explaining the separation of the clusters are generally located toward the zero origin and the more important variables are located on the periphery of the plot (Fig. 5b). The location of Z-linalool oxide and copaene on the left side and hexanal or hexyl formate on the right side of the $\mathrm{PC} 1$ axis indicates important variables, which are responsible for the separation of infected plants from non-infected plants. The PCA presented here reveals a strong shift in the relative proportion of the compounds due to infestation by BYDV. Table 3 shows that most compounds 

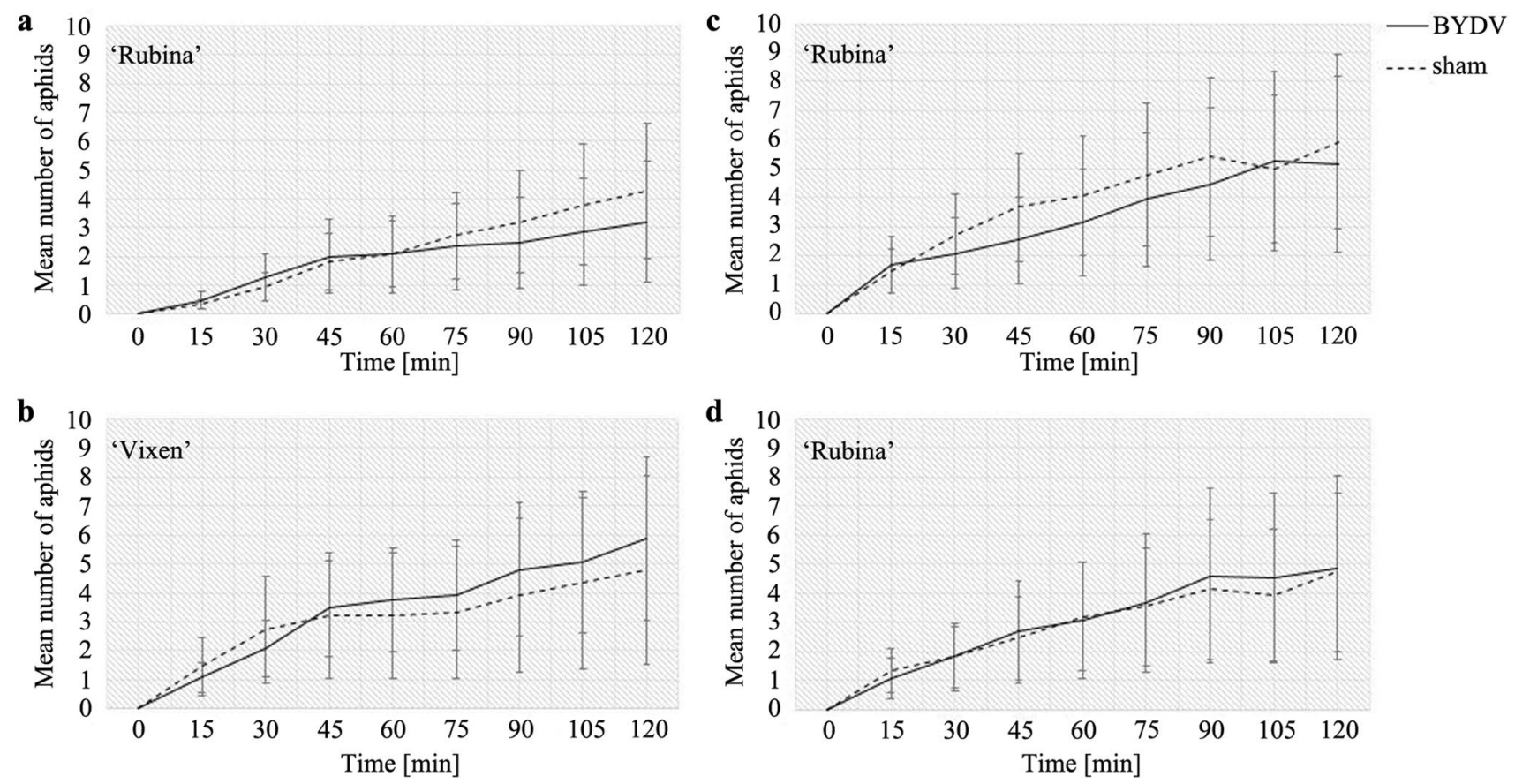

Fig. 3 Mean number of aphids per leaf on BYDV-infected and noninfected (sham) H. vulgare observed during $120 \mathrm{~min}$ after aphids were introduced. The $R$. padi clone R07 (high BYDV transmission efficiency) was tested on a the susceptible cv. 'Rubina' $(n=15)$ and $\mathbf{b}$ on the tolerant $\mathrm{cv}$. 'Vixen' $(n=9)$. Two further $R$. padi clones

are emitted in significantly higher proportions in infested plants compared to non-infested plants.

\section{Discussion}

Complex interactions between plants, insect virus vectors and viruses can have different outcomes depending on the benefit for the involved organisms and the capability of an organism to respond/or not to respond to the other actors. Jiménez-Martínez et al. (2004a) have shown that virus-susceptible wheat plants infected with BYDV are more suitable as hosts for $R$. padi than non-infected plants, leading to shorter development times of the aphids. In that case, nonviruliferous $R$. padi preferred the odor of susceptible BYDVinfected wheat cultivars over healthy plants after a period of $2 \mathrm{~h}$, whereas there was no preference for a transgenic tolerant wheat line (Jiménez-Martínez et al. 2004b; Medina-Ortega et al. 2009). In contrast, $R$. padi on barley showed no difference in host preference within the first $2 \mathrm{~h}$ for susceptible sham or BYDV-infected plants of the susceptible cultivar 'Rubina.' A significant, clone-specific host preference for $R$. padi was detected after a duration of $24 \mathrm{~h}$ for clone R07. Although aphids in our experiments needed more time for host selection, observations for the aphid clone R07 (which has a high BYDV transmission efficiency) are similar to

c D10 (medium BYDV transmission efficiency) $(n=8)$ and d R09 (low BYDV transmission efficiency) $(n=15)$ were exclusively tested on cv. 'Rubina.' Statistical test: ANOVA, Tukey HSD post hoc test: $\mathrm{p}>0.05$. Error bars indicate standard deviation

previous findings on wheat (e.g., Jiménez-Martínez et al. 2004b; Medina-Ortega et al. 2009). Comparable plant-vector-virus interactions have also been observed in a different vector plant system: volatiles from potato plants infected with potato leafroll virus attracted and arrested more aphids of the main virus vector Myzus persicae compared to healthy plants (Eigenbrode et al. 2002).

When offering sham and BYDV-infected plants of the tolerant cultivar 'Vixen', there was no preference of the clones, including R07, to infest BYDV-infected plants. Although the virus titer of the infected plants was high in both varieties, it is not this but rather the intensity of the symptom expression and here, finally, changes in the blend of volatile compounds (Jiménez-Martínez et al. 2004b) that cause variations in aphid behavior. The absence of volatile changes in infected 'Vixen' (a tolerant cultivar in which jasmonic acid is not produced after BYDV infection: Paulmann et al. 2018), illustrates the major role of jasmonic acid for volatile induction in plants (Boland et al. 1995).

Since BYDV infection of 'Rubina' plants induced differences in the aphid response, we compared singly potted sham and BYDV-infected 'Rubina' plants and found clear differences in the volatile emission between these two groups. Virus infection enhanced the emission of many compounds including aromatics, green leaf volatiles, monoterpenes and sesquiterpenes. The majority of these volatiles were 


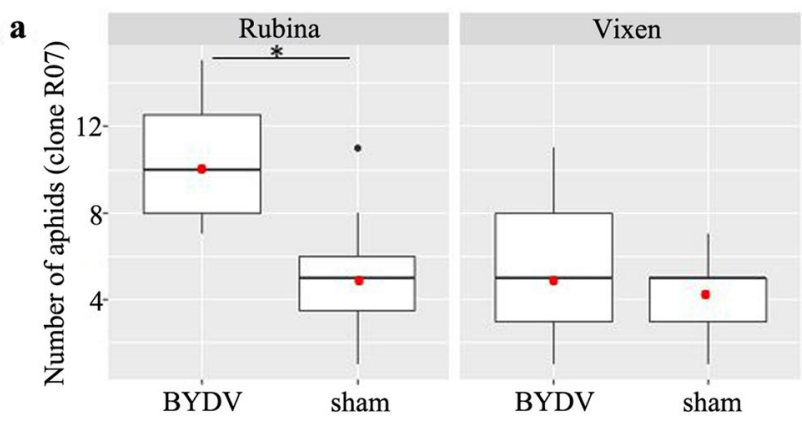

b

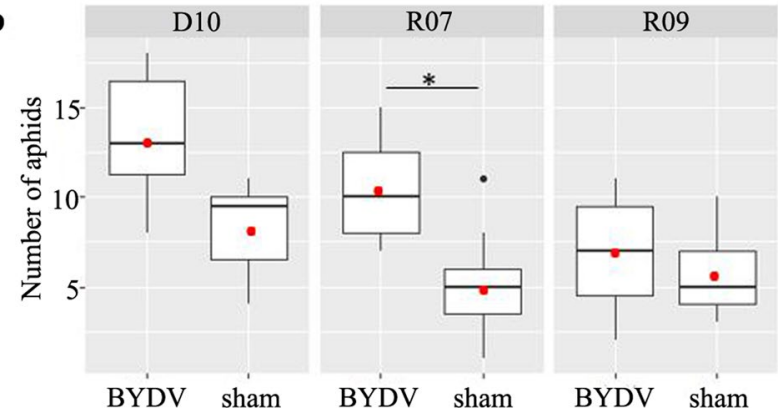

Fig. 4 Mean number of aphids per leaf on BYDV-infected and noninfected (sham) $H$. vulgare after an incubation period of $24 \mathrm{~h}$. a The $R$. padi clone R07 (high BYDV transmission efficiency) was tested on the susceptible cv. 'Rubina' $(n=15)$ and on the tolerant cv. 'Vixen' $(n=9)$. b Two further $R$. padi clones D10 (medium BYDV transmission efficiency) ( $n=8)$ and R09 (low BYDV transmission efficiency) $(n=15)$ were tested with R07 on cv. 'Rubina.' To make it easier to compare the different treatments, we have included R07 on cv. 'Rubina' in both figure parts. The red dots show the mean and black lines the median number of aphids. The whiskers show the upper and lower 1,5xIQR (interquartile range). Asterisk (*) mark significant differences. Statistical test: Two-tailed $t$-test: $p<0.01$

already found by Bukovinszky et al. (2005), Piesik et al. (2010, 2011) and Wenda-Piesik et al. (2010), who studied the effect of damage, insects and fungal infestation, respectively. The PCA presented here revealed a strong shift in the relative proportion of the compounds after BYDV infection, suggesting that barley reacts in a comparable way to wheat when infected with BYDV (Jiménez-Martínez et al. 2004a). Medina-Ortega et al. (2009) demonstrated an attractive effect for individual components such as Z-3-hexenyl acetate, undecane, decanal and E-beta-caryophyllene, detected for infected wheat plants, on $R$. padi. Our volatile analyses revealed similar, but not identical differences for the barley cv. 'Rubina'. The observation that BYDV-induced changes of the volatile composition of wheat and barley do not completely overlap suggests that only a few of those compounds may be sufficient to attract the aphids.

We assume that a clone-specific response to BYDVinfected cv. 'Rubina', as occurred for R. padi clone R07 when compared with D10 and R09, may be explained by different clone-specific sets of olfactory receptor genes, a gene family with, e.g., 45 candidates found in Aphis gossypii (Cao et al. 2014) and 79 candidates in Acyrthosiphon pisum (Smadja et al. 2009). Genetic characterization of $R$. padi clones has revealed different genetic clusters for Chinese (Duan et al. 2017) as well as for British (Morales-Hojas et al. 2019) populations, indicating genetic diversity between clones. Clone-specific sets of chemoreceptors might vary as a result of spontaneous mutations as well as long-term adaptation as proposed by Park and Hardie (2002) with regard to morphological changes during aphids' life cycle.

The preference for BYDV-infected plants, together with its high BYDV transmission efficiency, could give a fitness advantage to aphid clone R07. Mowry (1995) showed a positive correlation of the virus titer with the systemic spread of potato leafroll virus. $R$. padi clones may benefit from the ability to successfully detect, acquire and transmit BYDV, as BYDV infection of wheat accelerates nymphal development and increases total fecundity (Jiménez-Martinez et al. 2004a; Porras et al. 2018). Increased fecundity appears to be the result of a significant increase of essential amino acids in response to BYDV infection (Porras et al. 2018). Accelerated nymphal development as well as increased fecundity leads to an ecological advantage due to the rapid development of large populations that might compensate predation easier although predator species respond differently to cereal aphid population size, i.e., not all predators prefer to feed on big populations (Sunderland \& Vickerman, 1980). In the context of predation risk, Kersch-Becker and Thaler (2015) show that aphids feeding on aphid-resistant plants have a reduced risk of becoming prey of a predator when compared with aphids feeding on susceptible plants. They concluded that this effect is a result of a strong jasmonate plant defense in resistant plants. As described, Paulmann et al. (2018) observed that BYDV infection in BYDV-susceptible plants leads to an increase in jasmonate production, possibly causing an anti-predatory effect as observed by Kersch-Becker and Thaler (2015), which has to be proven in further studies. A BYDV-induced production of jasmonic acid is not observed in the BYDV-tolerant cultivar 'Vixen' (Paulmann et al. 2018), and it can therefore be assumed that there is no anti-predatory effect.

Jasmonic acid (JA) and jasmonic acid isoleucine conjugate (JA-Ile), e.g., found in soybean (Yates-Stewart et al. 2020), are involved in host plant resistance and were described to be induced in BYDV-infected 'Rubina' (Paulmann et al. 2018). We observed a host preference of such plants by the clone R07 with an increased ingestion on those plants when compared with sham-treated plants. These observations suggest that there is a suppressed or no host response to JA and JA-Ile. This could be based upon viral suppressors of RNA silencing (VSR) that enhance aphid performance, as shown for the interaction of the Cucumber mosaic virus (CMV), Nicotiana benthamiana and 

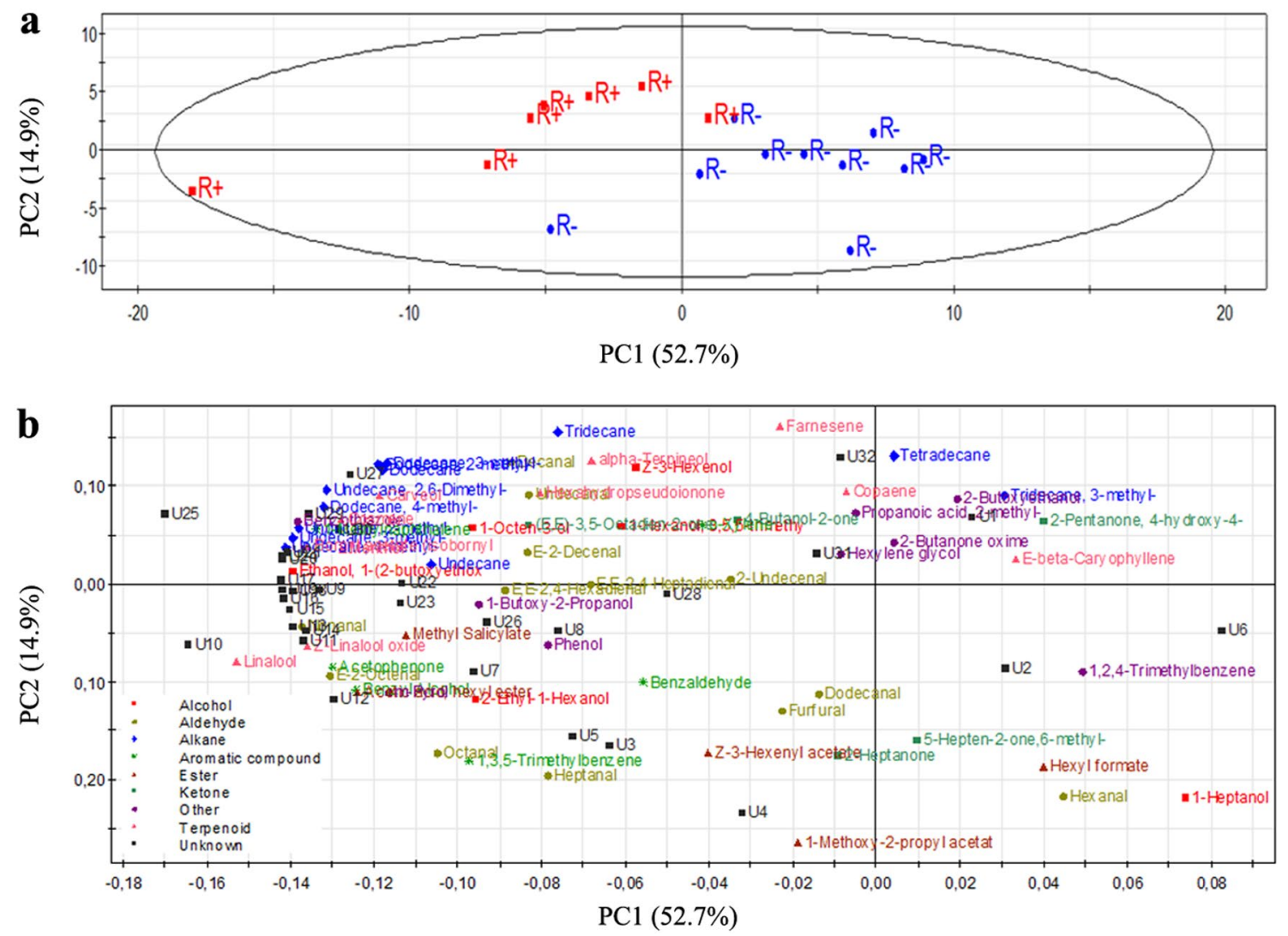

Fig. 5 Analysis of the volatile pattern of differently treated barley plants (Trial 2, one plant grown per pot). a Score plot and b loading plot from principal component analysis (PCA) based on relative amounts of volatile compounds (\% of the total measured emission of

Myzus persicae, whereat CMV infection enhances aphid performance (Westwood et al., 2014). In BYDV-PAV, the P4 movement protein was revealed to function as a main VSR (Fusaro et al. 2017). While D10 might benefit from a comparable BYDV infection related effect on the host as R07, the clone R09 showed a contrary response with significantly longer ingestion on sham-treated plants. Clonespecific differences might be related with the expression of different sets of salivary effectors that are secreted into SEs and interfere with plant defense responses, as recently shown for the pea aphid (Boulain et al., 2019). Except for D10 where ingestion-related differences occurred at 5 and $2 \mathrm{~h}$, those for D10 and R09 disappeared already after $2 \mathrm{~h}$.

Surprisingly, ingestion was significantly impaired for R07 on the BYDV-infected tolerant cv. 'Vixen', indicated by a reduced ingestion period in comparison with shamtreated plants. BYDV infection also leads to increased JA compounds) of 'Rubina' sham (R-) and BYDV-infected (R+) plants. The ellipse shown in the score plot defines the Hotelling's T2 confidence region $(95 \%)$

production in 'Vixen', as has been shown for abiotically challenged plants (Paulmann et al. 2018). We hypothesize that host-associated $\mathrm{R}$ proteins as part of the Ryd2-BYDV tolerance mechanism recognize VSRs that inhibit the activity of ARGONAUTE proteins as part of the antiviral RNA silencing pathway, thereby activating plant defense responses (studied in Moon and Park 2016), which would negatively affect $R$. padi. However, also on the susceptible cv. 'Rubina' the $R$. padi clone R07 does not only benefit from BYDV infection regarding increased ingestion, but shows increased stylet penetration problems during the first $2 \mathrm{~h}$ of recording when feeding on BYDV-infected plants.

Based upon our findings, we conclude that planting of the BYDV-tolerant barley cultivar 'Vixen' might have multiple benefits for farmers. Besides a lower impact on yield due to BYDV infection, the lower attraction of aphid virus 
Table 3 Variation of the phytochemical compositions (\%) of sham (R-) and BYDVinfected $(\mathrm{R}+)$ barley plants of 'Rubina'

\begin{tabular}{|c|c|c|c|c|c|c|}
\hline & M Non-infected & $\mathrm{SE}( \pm)$ & M Infected & $\mathrm{SE}( \pm)$ & $P$ & $\begin{array}{l}\text { Direc- } \\
\text { tion of } \\
\text { effect }\end{array}$ \\
\hline Unknown 1 & 0.000 & 0.000 & 0.005 & 0.005 & ns & \\
\hline 2-Butanone oxime & 0.000 & 0.000 & 0.004 & 0.006 & ns & \\
\hline Hexanal & 0.018 & 0.008 & 0.008 & 0.006 & $* *$ & $\mathrm{R}-$ \\
\hline 4-Butanol-2-one & 0.004 & 0.007 & 0.041 & 0.019 & $* * *$ & $\mathrm{R}+$ \\
\hline Furfural & 0.008 & 0.006 & 0.009 & 0.005 & ns & \\
\hline 4-Hydroxy-4-methyl-2-pentanone & 0.003 & 0.004 & 0.007 & 0.003 & ns & \\
\hline Z-3-Hexenol & 0.012 & 0.014 & 0.050 & 0.023 & $* *$ & $\mathrm{R}+$ \\
\hline Unknown 2 & 0.062 & 0.020 & 0.057 & 0.009 & ns & \\
\hline Hexyl formate & 0.368 & 0.116 & 0.269 & 0.041 & $*$ & $\mathrm{R}-$ \\
\hline 1-Methoxy-2-propyl acetate & 0.049 & 0.041 & 0.042 & 0.023 & ns & \\
\hline o-Xylene & 0.108 & 0.025 & 0.117 & 0.019 & ns & \\
\hline 2-Heptanone & 0.148 & 0.029 & 0.130 & 0.023 & ns & \\
\hline Heptanal & 0.043 & 0.027 & 0.045 & 0.018 & ns & \\
\hline 2-Butoxyethanol & 0.001 & 0.003 & 0.009 & 0.014 & ns & \\
\hline E,E-2,4-Hexadienal & 0.010 & 0.008 & 0.023 & 0.011 & $*$ & $\mathrm{R}+$ \\
\hline Hexylene glycol & 0.051 & 0.080 & 0.114 & 0.097 & $*$ & $\mathrm{R}+$ \\
\hline 1-Butoxy-2-Propanol & 0.004 & 0.005 & 0.011 & 0.006 & $*$ & $\mathrm{R}+$ \\
\hline Unknown 3 & 0.020 & 0.008 & 0.022 & 0.008 & ns & \\
\hline Benzaldehyde & 0.200 & 0.076 & 0.223 & 0.045 & ns & \\
\hline Unknown 4 & 0.089 & 0.020 & 0.073 & 0.021 & ns & \\
\hline 1,3,5-Trimethylbenzene & 0.045 & 0.024 & 0.052 & 0.029 & ns & \\
\hline 1-Heptanol & 0.076 & 0.035 & 0.031 & 0.010 & $*$ & $\mathrm{R}-$ \\
\hline Unknown 5 & 0.028 & 0.030 & 0.024 & 0.021 & ns & \\
\hline 1-Octen-3-ol & 0.012 & 0.012 & 0.052 & 0.018 & $* * *$ & $\mathrm{R}+$ \\
\hline Phenol & 0.060 & 0.021 & 0.073 & 0.020 & ns & \\
\hline 6-Methyl-5-hepten-2-one & 0.015 & 0.018 & 0.025 & 0.011 & ns & \\
\hline 1,2,4-Trimethylbenzene & 0.035 & 0.045 & 0.015 & 0.015 & ns & \\
\hline E,E-2,4-Heptadienal & 0.001 & 0.004 & 0.005 & 0.009 & ns & \\
\hline Octanal & 0.408 & 0.238 & 0.496 & 0.295 & ns & \\
\hline Unknown 6 & 0.206 & 0.106 & 0.091 & 0.032 & $*$ & $\mathrm{R}-$ \\
\hline Z-3-Hexenyl acetate & 0.005 & 0.015 & 0.021 & 0.023 & $*$ & $\mathrm{R}+$ \\
\hline Hexyl acetate & 0.025 & 0.020 & 0.057 & 0.048 & $*$ & $\mathrm{R}+$ \\
\hline 2-Ethyl-1-Hexanol & 0.153 & 0.049 & 0.143 & 0.104 & ns & \\
\hline Unknown 7 & 1.296 & 0.777 & 1.470 & 0.750 & ns & \\
\hline Unknown 8 & 0.253 & 0.418 & 0.583 & 1.204 & ns & \\
\hline Benzyl alcohol & 0.112 & 0.067 & 0.184 & 0.107 & $*$ & $\mathrm{R}+$ \\
\hline m-Pyrol & 0.045 & 0.025 & 0.058 & 0.041 & ns & \\
\hline 3,5,5-Trimethyl-1-hexanol & 0.059 & 0.025 & 0.130 & 0.054 & $* *$ & $\mathrm{R}+$ \\
\hline Unknown 9 & 0.097 & 0.068 & 0.198 & 0.078 & $*$ & $\mathrm{R}+$ \\
\hline E-2-Octenal & 0.140 & 0.084 & 0.234 & 0.121 & & $\mathrm{R}+$ \\
\hline Acetophenone & 0.231 & 0.149 & 0.421 & 0.283 & $*$ & $\mathrm{R}+$ \\
\hline Unknown 10 & 0.055 & 0.041 & 0.090 & 0.046 & ns & \\
\hline Z-Linalool oxide & 0.240 & 0.150 & 0.466 & 0.217 & $* *$ & $\mathrm{R}+$ \\
\hline Linalool & 0.151 & 0.101 & 0.202 & 0.124 & ns & \\
\hline Unknown 11 & 0.133 & 0.091 & 0.326 & 0.195 & $* *$ & $\mathrm{R}+$ \\
\hline (E,E)-3,5-Octadien-2-one & 0.033 & 0.032 & 0.013 & 0.034 & ns & \\
\hline Unknown 12 & 0.106 & 0.095 & 0.222 & 0.143 & * & $\mathrm{R}+$ \\
\hline Undecane & 0.060 & 0.105 & 0.315 & 0.262 & ns & \\
\hline Nonanal & 2.355 & 0.963 & 3.824 & 1.407 & $*$ & $\mathrm{R}+$ \\
\hline
\end{tabular}


Table 3 (continued)

\begin{tabular}{|c|c|c|c|c|c|c|}
\hline & M Non-infected & $\mathrm{SE}( \pm)$ & M Infected & $\mathrm{SE}( \pm)$ & $P$ & $\begin{array}{l}\text { Direc- } \\
\text { tion of } \\
\text { effect }\end{array}$ \\
\hline Unknown 13 & 0.037 & 0.031 & 0.098 & 0.053 & $* *$ & $\mathrm{R}+$ \\
\hline Unknown 14 & 0.038 & 0.019 & 0.073 & 0.025 & $* *$ & $\mathrm{R}+$ \\
\hline Unknown 15 & 0.176 & 0.123 & 0.422 & 0.201 & $* *$ & $\mathrm{R}+$ \\
\hline Cosmene & 0.222 & 0.116 & 0.660 & 0.145 & $* * *$ & $\mathrm{R}+$ \\
\hline Unknown 16 & 0.231 & 0.132 & 0.534 & 0.233 & $* *$ & $\mathrm{R}+$ \\
\hline Unknown 17 & 0.046 & 0.028 & 0.116 & 0.044 & $* *$ & $\mathrm{R}+$ \\
\hline Unknown 18 & 0.111 & 0.050 & 0.232 & 0.097 & $* *$ & $\mathrm{R}+$ \\
\hline Unknown 19 & 0.056 & 0.036 & 0.154 & 0.072 & $* *$ & $\mathrm{R}+$ \\
\hline Unknown 20 & 0.217 & 0.108 & 0.493 & 0.160 & $* * *$ & + \\
\hline Unknown 21 & 0.242 & 0.116 & 0.511 & 0.141 & $* * *$ & $\mathrm{R}+$ \\
\hline 4-Methyl-undecane & 0.278 & 0.121 & 0.582 & 0.149 & $* * *$ & $\mathrm{R}+$ \\
\hline 2-Methyl-undecane & 0.457 & 0.184 & 0.880 & 0.195 & $* * *$ & $\mathrm{R}+$ \\
\hline Unknown 22 & 0.050 & 0.075 & 0.209 & 0.106 & $* *$ & $\mathrm{R}+$ \\
\hline 3-Methyl-undecane & 0.375 & 0.152 & 0.785 & 0.194 & $* * *$ & $\mathrm{R}+$ \\
\hline Menthol & 0.022 & 0.021 & 0.055 & 0.057 & ns & \\
\hline Unknown 23 & 0.133 & 0.051 & 0.231 & 0.163 & $* *$ & $\mathrm{R}+$ \\
\hline Unknown 24 & 0.053 & 0.031 & 0.140 & 0.047 & $* * *$ & $\mathrm{R}+$ \\
\hline Alpha-terpineol & 0.249 & 0.115 & 0.497 & 0.203 & $*$ & $\mathrm{R}+$ \\
\hline 1-(2-Butoxyethoxy)-ethanol & 0.174 & 0.077 & 0.442 & 0.207 & $* * *$ & $\mathrm{R}+$ \\
\hline Methyl salicylate & 0.037 & 0.020 & 0.155 & 0.198 & $* * *$ & $\mathrm{R}+$ \\
\hline Dodecane & 2.130 & 0.764 & 3.442 & 0.576 & $* *$ & $\mathrm{R}+$ \\
\hline Decanal & 0.059 & 0.026 & 0.301 & 0.108 & $* * *$ & $\mathrm{R}+$ \\
\hline Carveol & 0.071 & 0.035 & 0.180 & 0.072 & $* *$ & $\mathrm{R}+$ \\
\hline 2,6-Dimethyl-undecane & 0.375 & 0.165 & 0.806 & 0.141 & $* * *$ & $\mathrm{R}+$ \\
\hline Benzothiazole & 0.055 & 0.031 & 0.137 & 0.034 & $* * *$ & $\mathrm{R}+$ \\
\hline Unknown 25 & 0.035 & 0.021 & 0.089 & 0.045 & $* *$ & $\mathrm{R}+$ \\
\hline Unknown 26 & 0.003 & 0.010 & 0.047 & 0.062 & ns & \\
\hline Unknown 27 & 0.066 & 0.029 & 0.130 & 0.023 & $* * *$ & \\
\hline 4-Ethyl-dodecane & 0.076 & 0.043 & 0.169 & 0.048 & $* * *$ & $\mathrm{R}+$ \\
\hline E-2-Decenal & 0.004 & 0.009 & 0.032 & 0.008 & $* * *$ & $\mathrm{R}+$ \\
\hline 2-Methyl-dodecane & 0.095 & 0.039 & 0.165 & 0.026 & $* *$ & $\mathrm{R}+$ \\
\hline Unknown 28 & 0.054 & 0.037 & 0.080 & 0.027 & $*$ & $\mathrm{R}+$ \\
\hline 3-Methyl-dodecane & 0.077 & 0.031 & 0.134 & 0.021 & $* *$ & $\mathrm{R}+$ \\
\hline Unknown29 & 0.024 & 0.016 & 0.062 & 0.015 & $* * *$ & $\mathrm{R}+$ \\
\hline Bornyl acetate (isobornyl acetate) & 0.017 & 0.007 & 0.038 & 0.012 & $* *$ & $\mathrm{R}+$ \\
\hline 1-Methylnaphthalene & 0.028 & 0.014 & 0.057 & 0.016 & $* *$ & $\mathrm{R}+$ \\
\hline Tridecane & 0.233 & 0.075 & 0.300 & 0.050 & $*$ & $\mathrm{R}+$ \\
\hline Undecanal & 0.003 & 0.006 & 0.013 & 0.012 & ns & \\
\hline Unknown 30 & 0.020 & 0.009 & 0.034 & 0.008 & $* *$ & $\mathrm{R}+$ \\
\hline Unknown 31 & 0.011 & 0.007 & 0.011 & 0.006 & ns & \\
\hline 2-Undecenal & 0.019 & 0.008 & 0.021 & 0.004 & ns & \\
\hline 3-MethyI-tridecane & 0.000 & 0.000 & 0.018 & 0.021 & $* *$ & $\mathrm{R}+$ \\
\hline 2-Methyl-propanoic acid & 0.021 & 0.006 & 0.020 & 0.004 & ns & \\
\hline Copaene & 0.001 & 0.002 & 0.010 & 0.005 & $* * *$ & $\mathrm{R}+$ \\
\hline Farnesane & 0.021 & 0.009 & 0.160 & 0.192 & $* * *$ & $\mathrm{R}+$ \\
\hline Tetradecane & 0.077 & 0.018 & 0.074 & 0.010 & ns & \\
\hline Hexahydropseudoionone & 0.009 & 0.005 & 0.013 & 0.002 & ns & \\
\hline Dodecanal & 0.005 & 0.006 & 0.007 & 0.005 & ns & \\
\hline E-beta-Caryophyllene & 0.004 & 0.005 & 0.001 & 0.002 & $\mathrm{~ns}$ & \\
\hline
\end{tabular}


Table 3 (continued)

\begin{tabular}{lllllll}
\hline & M Non-infected & $\mathrm{SE}( \pm)$ & M Infected & $\mathrm{SE}( \pm)$ & $P$ & $\begin{array}{l}\text { Direc- } \\
\text { tion of } \\
\text { effect }\end{array}$ \\
\hline Unknown 32 & 0.004 & 0.007 & 0.244 & 0.254 & $* * *$ & $\mathrm{R}+$ \\
\hline
\end{tabular}

$\mathrm{M}$ indicates the mean proportion of the compound, SE indicates the standard error, $\mathrm{P}$ indicates the level of significance $\left(* P<0.05, * * P<0.01,{ }^{*} * * P<0.001\right.$, n.s. non significant, Mann-Whitney $U$ post hoc tests corrected by Benjamini-Hochberg)

vectors with a high BYDV transmission rate would reduce the spread of BYDV from infected plants.

Supplementary Information The online version contains supplementary material available at https://doi.org/10.1007/s10340-021-01367-2.

Acknowledgments We thank Evelyn Betke, Kerstin Welzel and René Grünwald for excellent technical assistance.

Author Contribution MK, TM, ES, AH and TW conceived research, MK, TM and TW conducted experiments, MK, TM and TW analyzed data, MK, TM, TW and FO wrote and ES and AH reviewed and edited the manuscript. All authors read and approved the ms.

Funding Open Access funding enabled and organized by Projekt DEAL. No funding was received.

Availability of data and material Raw data as well as plant and insect material can be obtained on request.

\section{Declarations}

Conflicts of interest All authors declare that they have no conflict of interest.

Open Access This article is licensed under a Creative Commons Attribution 4.0 International License, which permits use, sharing, adaptation, distribution and reproduction in any medium or format, as long as you give appropriate credit to the original author(s) and the source, provide a link to the Creative Commons licence, and indicate if changes were made. The images or other third party material in this article are included in the article's Creative Commons licence, unless indicated otherwise in a credit line to the material. If material is not included in the article's Creative Commons licence and your intended use is not permitted by statutory regulation or exceeds the permitted use, you will need to obtain permission directly from the copyright holder. To view a copy of this licence, visit http://creativecommons.org/licenses/by/4.0/.

\section{References}

Adams RP (2014) Identification of essential oil components by gas chromatography/mass spectrometry, vol 456. Allured Publishing Corporation, Carol Stream, IL

Bencharki B, El Yamani M, Zaoui D (2000) Assessment of transmission ability of Barley yellow dwarf virus-PAV isolates by different populations of Rhopalosiphum padi and Sitobion avenae. Eur J Plant Pathol 106:455-464
Boland W, Hopke J, Donath J, Nüske J, Bublitz F (1995) Jasmonic acid and coronatin induce odor production in plants. Angew Chem Int Ed Engl 34:1600-1602

Boulain H, Legeai F, Jaquiéry J, Guy E, Morlière S, Simon J-C, Sugio A (2019) Differential expression of candidate salivary effector genes in pea aphid biotypes with distinct host plant specificity. Front Plant Sci 10:1301

Braendle C, Weisser WW (2001) Variation in escape behavior of red and green clones of the pea aphid. J Insect Behav 14:497-509

Bruce TJA, Wadhams LJ, Woodcock CM (2005) Insect host location: a volatile situation. Trends Plant Sci 10:269-274

Bukovinszky T, Gols R, Posthumus MA, Vet LEM, van Lenteren JC (2005) Variation in plant volatiles and attraction of the parasitoid Diadegma semiclausum (Hellén). J Chem Ecol 31:461-480

Cao D, Liu Y, Walker WB, Li J, Wang G (2014) Molecular characterization of the Aphis gossypii olfactory receptor gene families. PLoS ONE 9(6):e101187. https://doi.org/10.1371/journal.pone. 0101187

Chemistry WebBook NIST, SRD 69. (2002) NIST Standard Reference Database Number 69. National Institute of Standards and Technology, Gaithersburg, USA

Clark MF, Adams AN (1977) Characteristics of the microplate method of enzyme-linked immunosorbent assay for the detection of plant viruses. J Gen Virol 34:475-483

D'Arcy CJ (1995) Symptomatology and host range of barley yellow dwarf, Barley Yellow Dwarf. In: D’Arcy CJ, Burnett PA (eds) 40 Years of Progress. APS Press, St. Paul, pp 9-28

Dáder B, Then C, Berthelot E, Ducousso M, Ng JCK, Drucker M (2017) Insect transmission of plant viruses: multilayered interactions optimize viral propagation. Insect Sci 24:929-946

Döring TF (2014) How aphids find their host plants, and how they don't. Ann Appl Biol 165:3-26

Duan X, Peng X, Qiao X, Chen M (2017) Life cycle and population genetics of bird cherry-oat aphids Rhopalosiphum padi in China: an important pest on wheat crops. J Pest Sci 90:103-116

Eigenbrode SD, Ding H, Shiel P, Berger PH (2002) Volatiles from potato plants infected with potato leafroll virus attract and arrest the virus vector, Myzus persicae (Homoptera: Aphididae). Proc R Soc Lond B Biol Sci 269:455-460

Eriksson L, Johansson E, Kettaneh-Wold N, Wold S (2001) Multiand megavariate data analysis; principles and applications. Umetrics Academy, Sweden

Esau K (1957) Phloem degeneration in Gramineae affected by the Barley yellow-dwarf virus. Am J Bot 44:245

Ferrari J, Godfray HCJ, Faulconbridge AS, Prior K, Via S (2006) Population differentiation and genetic variation in host choice among pea aphids from eight host plant genera. Evolution 60:1574-1584

Fox J, Weisberg S (2019) An R Companion to Applied Regression, 3rd edn. Sage, Thousand Oaks. https://socialsciences.mcmaster. $\mathrm{ca} / \mathrm{jfox} /$ Books/Companion/.

Gray S, Gildow FE (2003) Luteovirus-aphid interactions. Ann Rev Phytopathol 41:539-566 
Gray SM, Power AG, Smith DM, Seaman AJ, Altman NS (1991) Aphid transmission of Barley yellow dwarf virus: acquisition access periods and virus concentration requirements. Phytopathology 81:539-545

Habekuss A, Leistner H-U, Schliephake E (1999) Characterisation of Rhopalosiphum padi genotypes differing in the geographical origin by transmission efficiency of Barley yellow dwarf viruses and molecular markers. J Plant Dis Prot 106:437-443

Ingwell LL, Eigenbrode SD, Bosque-Pérez NA (2012) Plant viruses alter insect behavior to enhance their spread. Sci Rep 2:578

Jensen SG (1969) Occurrence of virus particles in the phloem tissue of BYDV-infected barley. Virology 38:83-91

Jiménez-Martínez ES, Bosque-Pérez NA, Berger PH, Zemetra RS (2004a) Life history of the bird cherry-oat aphid, Rhopalosiphum padi (Homoptera: Aphididae), on transgenic and untransformed wheat challenged with Barley yellow dwarf virus. J Econ Entomol 97:203-212

Jiménez-Martínez ES, Bosque-Pérez NA, Berger PH, Zemetra RS, Ding H, Eigenbrode SD (2004b) Volatile cues influence the response of Rhopalosiphum padi (Homoptera: Aphididae) to Barley yellow dwarf virus-infected transgenic and untransformed wheat. Environ Entomol 33:1207-1216

Kersch-Becker MF, Thaler JS (2015) Plant resistance reduces the strength of consumptive and non-consumptive effects of predators on aphids. J Anim Ecol 84:1222-1232

Lenth RV (2016) Least-squares means: the R Package ismeans. J Stat Softw 69:1-33

Loxdale HD (2008) The nature and reality of the aphid clone: genetic variation, adaptation and evolution. Agr Forest Entomol 10:81-90

Medina-Ortega KJ, Bosque-Pérez NA, Ngumbi E, Jiménez-Martínez ES, Eigenbrode SD (2009) Rhopalosiphum padi (Hemiptera: Aphididae) responses to volatile cues from Barley yellow dwarf virus-infected wheat. Environ Entomol 38:836-845

Moon JY, Park JM (2016) Cross-talk in viral defense signalling in plants. Front Microbiol 7:2068

Morales-Hojas R, Gonzalez-Uriarte A, Iraizoz FA, Jenkins T, Alderson L, Kruger T, Hall MJ, Greenslade A, Shortall CR, Bell JR (2019) Genetic structure at national and regional scale in a long-distance dispersing pest organism, the bird cherry-oat aphid Rhopalosiphum padi. Biorxiv. https://doi.org/10.1101/829986

Mowry TM (1995) Within-plant accumulation of Potato leafroll virus by aggregated green peach aphid feeding. Phytopathology 85:859-863

Niks RE, Habekuß A, Bekele B, Ordon F (2004) A novel major gene on chromosome $6 \mathrm{H}$ for resistance of barley against the barley yellow dwarf virus. Theor Appl Genet 109:1536-1543

Park KC, Hardie J (2002) Functional specialisation and polyphenism in aphid olfactory sensilla. J Insect Physiol 48:527-535

Parry AL, Habgood RM (1986) Field assessment of the effectiveness of a Barley yellow dwarf virus resistance gene following its transference from spring to winter barley. Ann Appl Biol 108:395-401

Paulmann MK, Kunert G, Zimmermann MR, Theis N, Ludwig A, Meichsner D, Oelmüller R, Gershenzon J, Habekuss A, Ordon F, Furch ACU, Will T (2018) Barley yellow dwarf virus infection leads to higher chemical defense signals and lower electrophysiological reactions in susceptible compared to tolerant barley genotypes. Front Plant Sci 9:145

Piesik D, Łyszczarz A, Tabaka P, Lamparski R, Bocianowski J, Delaney KJ (2010) Volatile induction of three cereals: influence of mechanical injury and insect herbivory on injured plants and neighbouring uninjured plants. Ann Appl Biol 157:425-434

Piesik D, Panka D, Delaney KJ, Skoczek A, Lamparski R, Weaver DK (2011) Cereal crop volatile organic compound induction after mechanical injury, beetle herbivory (Oulema spp.), or fungal infection (Fusarium spp.). J Plant Physiol 168:878-886

Porras M, De Moras CM, Mescher MC, Rajotte EG, Carlo TA (2018) A plant virus (BYDV) promotes trophic facilitation in aphids on wheat. Sci Rep 8:11709

Powell G, Tosh CR, Hardie J (2006) Host plant selection by aphids: behavioral, evolutionary, and applied perspectives. Ann Rev Entomol 51:309-330

Prado E, Tjallingii WF (1994) Aphid activities during sieve element punctures. Entomol Exp Appl 72:157-165

R Development Core Team (2008) R: A language and environment for statistical computing. R Foundation for Statistical Computing, Vienna, Austria. ISBN 3-900051-07-0, URL http://www.R-proje ct.org.

Rochow WF (1961) The Barley yellow dwarf virus disease of small grains. In: Norman AG (ed) Advances in Agronomy. Academic Press, New York, pp 217-248

Schaller CW, Qualset CO, Rutger JN (1964) Inheritance and linkage of the $y d 2$ gene conditioning resistance to the barley yellow dwarf virus disease in barley. Crop Sci 4:544-548

Scheurer KS, Friedt W, Huth W, Waugh R, Ordon F (2001) QTL analysis of tolerance to a German strain of BYDV-PAV in barley (Hordeum vulgare L.). Theor Appl Genet 103:1074-1083

Schliephake E, Habekuss A, Scholz M, Ordon F (2013) Barley yellow dwarf virus transmission and feeding behaviour of Rhopalosiphum padi on Hordeum bulbosum clones. Ent Exp Appl 146:347-356

Šip V, Sirlova L, Chrpova J (2006) Screening for Barley yellow dwarf virus-resistant barley genotypes by assessment of virus content in inoculated seedlings. J Phytopathol 154:336-342

Slykhuis JT (1967) Methods for experimenting with mite transmission of plant viruses. Methods Virol 1:347-368

Smadja C, Shi P, Butlin RK, Robertson HM (2009) Large gene family expansions and adaptive evolution for odorant and gustatory receptors in the pea aphid, Acyrthosiphon pisum. Mol Biol Evol 26:2073-2086

Sunderland KD, Vickerman GP (1980) Aphid feeding by some polyphagous predators in relation to aphid density in cereal fields. J Appl Ecol 17:389-396

Tjallingii WF (1978) Electronic recording of penetration behaviour by aphids. Ent Exp Appl 24:521-530

Tjallingii WF (2006) Salivary secretions by aphids interacting with proteins of phloem wound responses. J Exp Bot 57:739-745

Tjallingii WF, Hogen Esch T (1993) Fine structure of aphid stylet routes in plant tissues in correlation with EPG signals. Physiol Entomol 18:317-328

van Den Dool H, Kratz PD (1963) A generalization of the retention index system including linear temperature programmed gas-liquid partition chromatography. J Chromatogr A 11:463-471

Wenda-Piesik A, Piesik D, Ligor T, Buszewski B (2010) Volatile organic compounds (VOCs) from cereal plants infested with crown rot: Their identity and their capacity for inducing production of VOCs in uninfested plants. Int J Pest Manag 56:377-338

Westwood JH, Lewsey MG, Murphy AM, Tungadi T, Bates A, Gilligan CA, Carr JP (2014) Interference with jasmonic acid-regulated gene expression is a general property of viral suppressors of RNA silencing but only partly explains virus-induced changes in plantaphid interactions. J Gen Virol 95:733-739

Wold S, Esbensen K, Geladi P (1987) Principal component analysis. Chemometr Intell Lab Syst 2:37-52

Yates-Stewart A, Pekarcik A, Michel A, Blakeslee JJ (2020) Jasmonic acid-isoleucin (JA-Ile) is involved in the host-plant resistance mechanism against the soybean aphid (Hemiptera: Aphididae). J Econ Entomol. https://doi.org/10.1093/jee/toaa221 
Lenth R, Singmann H, Love J, Buerkner PH (2019) emmeans: estimated marginal means, aka least-squares means. $\mathrm{R}$ package $\mathrm{v}$. 1.3. 4 .
Publisher's Note Springer Nature remains neutral with regard to jurisdictional claims in published maps and institutional affiliations. 